vary with the amount of carotene in the food, thus being richer in summer than in winter. It

TABLE 5

Carotene and Vitamin a Values of Shorthorn and GUernsey

\begin{tabular}{ccccc} 
BUTMER FATS UNDER IDENTICAL CONDITIONS OF FEEDING \\
& \multicolumn{2}{c}{ Shorthorn } & \multicolumn{2}{c}{ Guernsey } \\
& Carotene & Vitamin A & Carotene & Vitamin A \\
ummer & 0.78 & 1.10 & $2 \cdot 24$ & 0.89 \\
utumn & 0.67 & 0.93 & 1.80 & 0.70 \\
Vinter & 0.19 & 0.39 & 0.50 & 0.34 \\
& (Values as mgm. per $100 \mathrm{gm}$. fat). &
\end{tabular}

Comparison of the Carotene and Vitamin a Values of the Fat of ORdinary and Colostrom MilK (Individual Cows Chosen at RANDOM) Carotene vitamin A

\begin{tabular}{|c|c|c|c|}
\hline Breed & Date of sample & $\begin{array}{l}\text { Carotene } \\
\text { (mgm. \% fat) }\end{array}$ & $\begin{array}{l}\text { Vitamin A } \\
\text { (mgm. \% fat) }\end{array}$ \\
\hline Friesian & $\begin{array}{l}\text { Oct. } 20 \\
\text { Nov. } 20\end{array}$ & $\begin{array}{l}3 \cdot 40 \\
0 \cdot 38\end{array}$ & $\begin{array}{l}1.24 \\
0.52\end{array}$ \\
\hline Ayrshire & $\begin{array}{l}\text { Nov. } 22 \\
\text { Dec. } 22\end{array}$ & $\begin{array}{l}4 \cdot 60 \\
0 \cdot 18\end{array}$ & $\begin{array}{l}2 \cdot 96 \\
0.37\end{array}$ \\
\hline Guernsey & $\begin{array}{l}\text { Oct. } 28 \\
\text { Nov. } 28\end{array}$ & $\begin{array}{l}3 \cdot 61 \\
0.91\end{array}$ & $\begin{array}{l}1.13 \\
0.67\end{array}$ \\
\hline Shorthorn & $\begin{array}{l}\text { Oct. } 13 \\
\text { Nov. } 13\end{array}$ & $\begin{array}{l}2 \cdot 90 \\
0 \cdot 28\end{array}$ & $\begin{array}{l}3 \cdot 51 \\
0.48\end{array}$ \\
\hline
\end{tabular}

is also interesting to note that the serum of cows is distinctly richer than is that of bulls, but whether this is due to a genuine sex difference or to different conditions of management has yet to be ascertained (cf. Table 7 due to Gillam and El Ridi).

\begin{tabular}{lcccc} 
Table 7 \\
Carotene and Vitamin A in Cow's Blood Sera (Average Values) \\
Cows & \multicolumn{2}{c}{ Bulls } \\
Winter & Carotene & Vitamin A & Carotene & Vitamin A \\
Summer & 0.40 & 0.13 & 0.08 & 0.05 \\
& 1.11 & 0.29 & 0.42 & 0.14
\end{tabular}

(All values as mgm. per $100 \mathrm{ml}$. of serum.)

We have attempted in the foregoing to trace the stages in the development of our knowledge of the lipochrome pigments and to show how, by the application of the elegant methods now used by the organic chemist, the constitution of the more important of these natural polyenes has been elucidated. Apart from the intrinsic interest of this work, it has led to the fundamental discovery of the close interrelation between carotene and vitamin $A$, one of the indispensable key substances of life.

\title{
Fire-Walking: Scientific Tests
}

$\mathrm{E}^{\mathrm{I}}$ IGHTEEN months ago, the University of London Council for Psychical Investigation arranged a demonstration of fire-walking, with the view of obtaining precise information upon its scientific aspects. Descriptions of the condition of the feet of the performer, Kuda Bux, before and after the walk, and results of some physical observations, were given in NATURE of September 21 and 28, $1935(136,468,521)$. As the observations were not altogether conclusive, two more demonstrations were arranged by the University of London Council for Psychical Investigation through Mr. Harry Price, honorary secretary of the Council, in the grounds of Mr. Alex. Dribbell at Carshalton, Surrey, on April 8 and 10.

The professional fire-walker was Ahmed Hussain, a Moslem from Cawnpore. In the first experiment, the trench containing the charcoal on oak-ash was $12 \mathrm{ft}$. long. The temperatures were measured by special thermocouples with the co-operation of the Cambridge Scientific Instrument Co., Ltd., and were shown to be $575^{\circ} \mathrm{C}$. on the surface and $700^{\circ} \mathrm{C}$. inside. After examination and tests for chemical treatment, Hussain walked the trench in $1 \cdot 3$ sec., showing no signs of injury. He then repeated the walk leading three amateur volunteers with the claim that they would be immune from burning. They were, however, all burned to a varying but slight degree. A further two volunteers then performed the walk separately and unaided. They were also slightly burned, and where the number of steps had been uneven, the foot that had been down most often was most affected. This indicated that the injurious effect was cumulative, although Hussain claimed that he could walk any distance. As he refused to retrace his steps, the trench was increased to $20 \mathrm{ft}$. for the second experiment.

In the second experiment, the surface temperature was $740^{\circ} \mathrm{C}$. and the inside $750^{\circ} \mathrm{C}$. Hussain took six steps in $2 \cdot 3$ sec., and this produced five blisters on one foot and marked erythema on the other, a condition closely resembling that of the amateurs after four steps. The effect was therefore cumulative in his case also. One of the former volunteers covered the distance in four steps and 1.4 sec., and then later, in rope-soled shoes, took seven steps in 3.6 sec. The frayed portions of the rope were slightly scorched at the edges only. The feet sank into the ash to a depth of between two and three inches, and it seems clear that its poor thermal conductivity prevents damage to normal skin if the contact-time is less than about half a second, although the small flames within it will produce singeing of the hairs. This time corresponds with that of one quick step: two steps with the same foot could only be done without injury by the practised professional, and three steps was beyond his limit.

This small difference between amateur and professional, together with observations made during the experiment, make it very unlikely that any hypothesis of a special induced mental state is required, such as is, of course, maintained by the Indian performers. 